\title{
Association of Polymorphisms in X-Ray Repair Cross Complementing 1 Gene and Risk of Esophageal Squamous Cell Carcinoma in a Chinese Population
}

\author{
Yu-Xia Yun, ${ }^{1,2}$ Li-Ping Dai, ${ }^{1}$ Peng Wang, ${ }^{1}$ Kai-Juan Wang, ${ }^{1}$ Jian-Ying Zhang, ${ }^{1}$ and Wei Xie ${ }^{1}$ \\ ${ }^{1}$ Department of Radiology, The First Affiliated Hospital \& Department of Epidemiology, College of Public Health and Henan Key \\ Laboratory of Tumor Epidemiology, Zhengzhou University, Zhengzhou, Henan 450052, China \\ ${ }^{2}$ Department of Immunization Planning, Centers for Disease Control and Prevention of Puyang City, Puyang, Henan 457000, China
}

Correspondence should be addressed to Li-Ping Dai; lpdai@hotmail.com and Wei Xie; wxie1970@hotmail.com

Received 11 November 2014; Revised 30 November 2014; Accepted 2 December 2014

Academic Editor: David B. Ordiz

Copyright (C) $2015 \mathrm{Yu}$-Xia Yun et al. This is an open access article distributed under the Creative Commons Attribution License, which permits unrestricted use, distribution, and reproduction in any medium, provided the original work is properly cited.

\begin{abstract}
Objectives. To investigate the association between three single nucleotide polymorphisms (SNPs) in the X-ray repair cross complementing 1 gene (XRCC1) and the risk of esophageal squamous cell carcinoma (ESCC) in Chinese population. Methods. A case-control study including 381 primary ESCC patients recruited from hospital and 432 normal controls matched with patients by age and gender from Chinese Han population was conducted. The genotypes of three XRCC1 polymorphisms at $-77 \mathrm{~T}>\mathrm{C}$ (T-77C), codon 194 (Arg194Trp), and codon 399 (Arg399Gln) were studied by means of polymerase chain reaction-restriction fragment length polymorphism techniques (PCR-RFLP). Unconditional logistic regression model and haplotype analysis were used to estimate associations of these three SNPs in XRCC1 gene with ESCC risk. Results. Polymorphisms at these three sites in $X R C C 1$ gene were not found to be associated with risk for developing ESCC; however the haplotype $\mathrm{C}_{\text {codon } 194} \mathrm{G}_{\text {codon } 399} \mathrm{C}_{-77 \mathrm{~T}>\mathrm{C}}$ was significantly associated with reduced risk of ESCC (OR: 0.62, 95\% CI: 0.40-0.96) upon haplotype analysis. Conclusion. These results suggested that the gene-gene interactions might play vital roles in the progression on esophageal cancer in Chinese Han population and it would be necessary to confirm these findings in a large and multiethnic population.
\end{abstract}

\section{Introduction}

Esophageal cancer (EC) is the eighth most common malignancy and the sixth most common cause of cancer-related deaths worldwide, responsible for $3.8 \%$ of all new cancer cases and for $5.4 \%$ of cancer related deaths each year [1-5]. In 2008, about 482,000 new cases occurred and 406,000 patients died from EC worldwide, over $83 \%$ of which were in developing countries [2]. EC is the fourth leading cause of cancer death in China [6], with approximately 250,000 cases diagnosed yearly, and it contributes to about half of the cases of the world $[4,5,7-10]$.

Base excision repair (BER) is one of the important DNA repair pathways against DNA damage that could lead to cancer resulted from many factors, including altered metabolism, reactive oxygen species, and methylating and deaminating agents [7-10]. The BER pathway has a primary role in the repair of oxidative base lesions such as 8-hydroxyguanine, formamidopyrimidines, and 5-hydroxyuracil [11]. Oxidative damage to DNA may lead to mutations that activate oncogenes or inactivate tumor suppressor genes and may eventually increase the probability of genetic alterations developing into neoplastic events [11]. Sequence variants in BER genes are thought to modulate DNA repair capacity and are consequently suspected of being associated with altered cancer risk [12]. XRCC1 protein encoded by XRCC1 gene plays a critical role involved in the BER pathway, which interacts with enzymatic components of each stage of DNA strand break repair, including DNA polymerase beta, APE1 (apurinic/apyrimidinic endonuclease 1), PARP-1 (poly [ADPribose] polymerase 1), and DNA ligase III [13-18]. There are more than 60 validated single nucleotide polymorphisms (SNPs) in the XRCC1 gene containing 17 exons and 16 introns on chromosome 19q13.2-13.3, among which three 
TABle 1: Primer sequences and restriction endonucleases of three SNPs in XRCC1 gene.

\begin{tabular}{|c|c|c|c|c|c|}
\hline SNPs & Location & Position & Primers & Enzymes & Digested fragments \\
\hline codon 194 & exon 6 & $\mathrm{C} 26304 \mathrm{~T}$ & $\begin{array}{l}\text { F: GCCAGGGCCCCTCCTTCAA } \\
\text { R: TACCCTCAGACCCACGAGT }\end{array}$ & PvuII & $\begin{array}{c}\text { CC }(485) \\
\text { CT }(485,396,89) \\
\text { TT }(396,89) \\
\end{array}$ \\
\hline codon 399 & exon 10 & G28152A & $\begin{array}{l}\text { F: TTGTGCTTTCTCTGTGTCCA } \\
\text { R: TCCTCCAGCCTTTTCTGATA }\end{array}$ & MspI & $\begin{array}{c}\text { GG }(374,241) \\
\text { GA }(615,374,241) \\
\text { AA }(615)\end{array}$ \\
\hline$-77 \mathrm{~T}>\mathrm{C}$ & $5^{\prime} \mathrm{UTR}$ & $\mathrm{T}-77 \mathrm{C}$ & $\begin{array}{l}\text { F: GGTTCTGGAAGCCACTCA } \\
\text { R: GGGCTGAGGGCCTAAAC }\end{array}$ & BsrB I & $\begin{array}{c}\mathrm{TT}(167,67) \\
\mathrm{TC}(234,167,67) \\
\mathrm{CC}(234)\end{array}$ \\
\hline
\end{tabular}

polymorphisms in the XRCC1 gene at the $-77 \mathrm{~T}>\mathrm{C}\left(5^{\prime}\right.$ end, T to C), codon 194 (exon 6, Arg to Trp), and codon 399 (exon 10, Arg to Gln) have been studied.

The genetic polymorphism of XRCC1 codon 194 results in an arginine to tryptophan amino acid substitution and occurs at a conserved residue in humans, hamsters, and mice, and this evolutionary conservation suggests that this site is functionally important $[19,20]$. The genetic polymorphism in the XRCC1 gene at codon 399 results in an arginine to glutamine amino acid substitution. A report of Lunn and colleagues measured the prevalence of aflatoxin B1 adducts in placental DNA from 120 Taiwanese women and suggested that the XRCC1 codon 399 polymorphism may result in deficient DNA repair capacity [21]. The result of Hao et al. [22] showed that $-77 \mathrm{~T}>\mathrm{C}$ can increase the combination of XRCC1 promoter and a transcription inhibitory factor, thus reducing the promoter activity and protein expression. Because amino acid residues at the protein-protein interfaces of multiprotein complexes and residues involved in the active sites play a role in enzyme function, it is possible that $X R C C 1$ polymorphisms lead to alteration of DNA repair capacity.

Thus, we conducted this case-control study to comprehensively investigate the role of the polymorphisms (codon 194 , codon 399, and -77T >C) in XRCC1 gene in the development of ESCC in a Chinese Han population.

\section{Materials and Methods}

2.1. Study Population and Sample Collection. This case-control study included 381 newly histopathologically diagnosed primary ESCC patients recruited at the First Affiliated Hospital and the Second Affiliated Hospital of Zhengzhou University between March 2008 and January 2010. All ESCC patients had no prior history of other types of cancer and were not previously treated with chemotherapy or radiotherapy. Uniform trained investigators used the special questionnaire containing information of age, sex, tobacco smoking, alcohol intake, family history of cancer, and environmental factors to interview patients face to face after written informed consent. 432 normal controls were frequently matched by age $( \pm 5$ years) and gender with patients randomly selected from a census of digestion diseases that we had conducted previously from March 2003 to July 2005 in Xinxiang County of Henan Province. Controls were required to be free of any digestion diseases with written informed consent, having no cancer history and related clinical signs. All the subjects were ethnic Han Chinese without immediate family relations.

The $5 \mathrm{~mL}$ venous blood samples obtained from the subjects were collected in an EDTA tube and stored at $-70^{\circ} \mathrm{C}$ for extraction of DNA genome. Tobacco smoking was defined as smoking at least one cigarette per day and persisting for more than one year. Alcohol intake was defined as drinking at least once a week with more than 100 gram every time and persisting for more than six months. This study was approved by the Institutional Review Board of Zhengzhou University. Informed consent was obtained from each study participant.

2.2. XRCC1 Genotyping. The genotypes of XRCC1 polymorphisms were determined by PCR-RFLP. Primers and restriction endonucleases are shown in Table 1.

The PCR reaction started with a total volume of $15 \mu \mathrm{L}$ for each mixture containing the following reagents: $7.5 \mu \mathrm{L} 2 \times$ Taq PCR MasterMix, $0.5 \mu \mathrm{M}$ each primer, $1.0 \mu \mathrm{L}$ (50 ng) DNA, and $5.6 \mu \mathrm{L}$ deionized water.

PCR conditions were as follows:

codon 194: $95^{\circ} \mathrm{C}$ for $2 \mathrm{~min}$, followed by 35 cycles of $94^{\circ} \mathrm{C}$ for $30 \mathrm{~s}, 60^{\circ} \mathrm{C}$ for $30 \mathrm{~s}, 72^{\circ} \mathrm{C}$ for $45 \mathrm{~s}$, and a final elongation step at $72^{\circ} \mathrm{C}$ for $7 \mathrm{~min}$,

codon 399: $94^{\circ} \mathrm{C}$ for $5 \mathrm{~min}$, followed by 35 cycles of $94^{\circ} \mathrm{C}$ for $30 \mathrm{~s}, 57^{\circ} \mathrm{C}$ for $30 \mathrm{~s}, 72^{\circ} \mathrm{C}$ for $45 \mathrm{~s}$, and a final elongation step at $72^{\circ} \mathrm{C}$ for $5 \mathrm{~min}$,

$-77 \mathrm{~T}>\mathrm{C}: 94^{\circ} \mathrm{C}$ for $5 \mathrm{~min}$, followed by 35 cycles of $94^{\circ} \mathrm{C}$ for $30 \mathrm{~s}, 60^{\circ} \mathrm{C}$ for $30 \mathrm{~s}, 72^{\circ} \mathrm{C}$ for $30 \mathrm{~s}$, and a final elongation step at $72^{\circ} \mathrm{C}$ for $5 \mathrm{~min}$.

The digested products were resolved on 2\% agarose gels (for codons 194 and 399), 3\% agarose gels (for $-77 \mathrm{~T}>\mathrm{C}$ ) and stained with $0.5 \mu \mathrm{g} / \mathrm{mL}$ ethidium bromide.

All assays were repeated at least once by the same individual it is not relevant to verify the genotyping results. Genotypes were validated by sequencing through biological technology company.

2.3. Statistical Analysis. All analyses were conducted by SPSS16.0 software. To determine whether the frequencies between cases and controls were significantly different $(\alpha=$ $0.05)$, the $\chi^{2}$ test was used. And $\chi^{2}$ test was also used to compare distribution differences of haplotype, combined 
TABLE 2: Characteristics of esophageal cancer cases and controls.

\begin{tabular}{lcccc}
\hline Variables & $\begin{array}{c}\text { Case } N \\
(\%)\end{array}$ & $\begin{array}{c}\text { Control } N \\
(\%)\end{array}$ & $\chi^{2}$ & $P$ \\
\hline Age & $N=381$ & $N=432$ & & \\
$\quad \leq 65$ & $237(62.2)$ & $286(66.2)$ & 1.41 & 0.23 \\
$>65$ & $144(37.8)$ & $146(33.8)$ & & \\
Gender & & & & \\
$\quad$ Male & $256(67.2)$ & $278(64.4)$ & 0.72 & 0.40 \\
$\quad$ Female & $125(32.8)$ & $154(35.6)$ & & \\
Smoking* & & & & \\
$\quad$ Nonsmokers & $189(59.6)$ & $264(61.1)$ & 0.17 & 0.68 \\
$\quad$ Smokers & $128(40.4)$ & $168(38.9)$ & & \\
Drinking* & & & & \\
$\quad$ Nondrinkers & $255(80.7)$ & $353(81.9)$ & 0.18 & 0.68 \\
$\quad$ Drinkers & $61(19.3)$ & $78(18.1)$ & & \\
Family history of cancer* & & & & \\
$\quad$ No & $233(75.6)$ & $357(85.2)$ & 10.60 & 0.001 \\
$\quad$ Yes & $75(24.4)$ & $62(14.8)$ & & \\
\hline
\end{tabular}

* because of the failure data collection, the number of cases and controls for some factors was less than 381 or 432 .

genotype, the number of mutation sites, and the number of mutation alleles among three genetic polymorphisms.

Online software http://www.had2know.com/academics/ hardy-weinberg-equilibrium-calculator-2-alleles.html was used to assess Hardy-Weinberg equilibrium for genotype frequency in controls by a Pearson's goodness-of-fit $\chi^{2}$ test to compare the observed genotype frequencies to the expected ones, with one degree of freedom. Odds ratios (ORs) and 95\% confidence intervals (95\%CI) from logistic regression analysis for crude ORs and adjusted ORs when adjusting for age, gender, smoking, drinking, and family history of cancer were used to detect the associations between these three polymorphisms and ESCC risk. Haplotypes for each individual were inferred using the SNPHAP 2.0 software. Statistical tests were two sided and were considered statistically significant whenever $P<0.05$.

\section{Results}

3.1. Subject Characteristics. The frequency distribution of age, sex, smoking, alcohol drinking status, and family history of cancer among the study subjects is summarized in Table 2. The number of individuals with a family history of cancer was higher in ESCC cases than in normal controls $\left(\chi^{2}=10.60\right.$, $P=0.001)$.

3.2. ESCC Risk Associated with Individual SNPs. The genotype distributions of the three studied SNPs in controls were all in accordance with Hardy-Weinberg equilibrium; the $P$ value was $0.28,0.79$, and 0.09 for codon 194 , codon 399 , and $-77 \mathrm{~T}>\mathrm{C}$, respectively.
As shown in Table 3, the distributions of heterozygous and homozygous genotypes of XRCC1 codon 194 and codon 399 did not show statistically significant difference between the cases and controls $(P>0.05)$, and the results were the same after adjustment for age, gender, smoking, drinking, and family history of cancer. The heterozygous genotype TC, combined genotype TC or CC, and allele C of XRCC1 $-77 \mathrm{~T}>\mathrm{C}$ may decrease risk of ESCC; however, there was no significantly statistical association after adjusting age, gender, smoking, drinking, and family history of cancer.

3.3. Haplotype Analysis. In order to study the haplotypes for XRCC1 codon 194, codon 399, and -77T>C, SNPHAP 2.0 software was applied, showing a total of eight built haplotypes. Table 4 shows the frequencies of the estimated haplotypes among patients and controls. For every susceptibility analysis of a haplotype, the haplotype CGT (codon 194, codon 399, and $-77 \mathrm{~T}>\mathrm{C}$ ) containing major allele was taken as control. The data of Table 4 indicated that only haplotype CGC (codon 194, codon 399, and $-77 \mathrm{~T}>\mathrm{C}$ ) may decrease risk for developing ESCC compared to the control after adjusting age, gender, smoking, drinking, and family history of cancer (OR: 0.62, 95\% CI: 0.40-0.96).

3.4. Combined Genotypes Analysis of XRCC1 Codon 194, Codon 399, and $-77 T>C$. Using combined wild genotype CC/GG/TT as control, combined mutation genotype CT/GG/CT may decrease the risk in developing ESCC (OR: 0.46, 95\% CI: $0.22-0.96, P=0.04)$. But after adjusting age, gender, smoking, drinking, and family history of cancer, combined mutation genotype CT/GG/CT has no statistical association with ESCC (Table 5).

3.5. Trend Analysis of the Number of Mutation Sites. We performed trend analysis of the association between the number of mutation sites and risk of ESCC. Using null-mutation of three SNPs as control, there was no statistically significant association of one site mutation, two sites mutation, and three sites mutation with ESCC susceptibility (trend $\chi^{2}=0.38$, $P=0.54)$ (Table 6).

\section{Discussion}

Environmental and genetic factors as identifiable risk factors are considered to have a significant contribution in the development of cancer. Some studies have found that environmental factors including tobacco smoking, alcohol consumption, nitrates, and preformed nitrosocompounds can increase EC risk $[23,24]$. However, not all individuals who have been exposed to the environmental risk factors actually develop EC, suggesting that genetic susceptibility might contribute to the individual risk of EC. XRCC1 polymorphisms have been reported to be associated with the risk of different kinds of cancers, including gastric cancer, colorectal cancer, lung cancer, and breast cancer [25-28].

Our data showed that there was no significant association between polymorphism of XRCC1 codon 194 and ESCC susceptibility, and some results of the domestic and foreign 
TABLE 3: Association of XRCC1 genotypes with esophageal cancer.

\begin{tabular}{|c|c|c|c|c|c|c|c|}
\hline Genotypes & $\begin{array}{l}\text { Case } \\
N(\%)\end{array}$ & $\begin{array}{c}\text { Control } \\
N(\%)\end{array}$ & $\chi^{2}$ & OR $(95 \% \mathrm{CI})$ & $P$ & OR $(95 \% \mathrm{CI})^{*}$ & $P^{*}$ \\
\hline \multicolumn{8}{|l|}{ Codon 194} \\
\hline $\mathrm{CC}$ & $166(46.6)$ & $187(44.6)$ & Reference & 1.00 & - & - & - \\
\hline $\mathrm{TC}$ & $159(44.7)$ & $193(46.1)$ & 0.24 & $0.93(0.69,1.25)$ & 0.62 & $0.91(0.66,1.26)$ & 0.57 \\
\hline TT & $31(8.7)$ & $39(9.3)$ & 0.18 & $0.90(0.53,1.50)$ & 0.67 & $0.96(0.55,1.68)$ & 0.90 \\
\hline $\mathrm{CC}+\mathrm{TC}$ & $190(53.4)$ & $232(55.4)$ & 0.31 & $0.92(0.69,1.23)$ & 0.58 & $0.92(0.68,1.25)$ & 0.59 \\
\hline $\mathrm{C}$ & $567(67.7)$ & $491(69.0)$ & Reference & 1.00 & - & - & - \\
\hline $\mathrm{T}$ & $271(32.3)$ & $221(31.0)$ & 0.30 & $1.06(0.86,1.32)$ & 0.58 & $0.90(0.76,1.21)$ & 0.70 \\
\hline \multicolumn{8}{|l|}{ Codon 399} \\
\hline GG & $184(48.5)$ & $223(51.6)$ & Reference & 1.00 & - & - & - \\
\hline GA & $166(43.8)$ & $169(40.7)$ & 1.39 & $1.19(0.89,1.59)$ & 0.24 & $1.14(0.84,1.57)$ & 0.40 \\
\hline $\mathrm{AA}$ & $29(7.7)$ & $30(7.7)$ & 0.32 & $1.17(0.68,2.02)$ & 0.57 & $1.03(0.57,1.86)$ & 0.92 \\
\hline $\mathrm{GA}+\mathrm{AA}$ & $195(51.5)$ & $199(47.2)$ & 1.47 & $1.47(0.22,1.57)$ & 0.22 & $1.13(0.83,1.52)$ & 0.44 \\
\hline G & $534(70.4)$ & $615(72.9)$ & Reference & 1.00 & - & - & - \\
\hline A & $224(29.6)$ & $229(27.1)$ & 1.15 & $1.13(0.91,1.40)$ & 0.28 & $1.07(0.85,1.35)$ & 0.57 \\
\hline \multicolumn{8}{|l|}{$-77 \mathrm{~T}>\mathrm{C}$} \\
\hline TT & $310(83.6)$ & $319(77.2)$ & Reference & 1.00 & - & - & - \\
\hline $\mathrm{TC}$ & $59(15.9)$ & $92(22.3)$ & 5.09 & $0.66(0.46,0.95)$ & 0.02 & $0.70(0.48,1.03)$ & 0.07 \\
\hline $\mathrm{CC}$ & $2(0.5)$ & $2(0.5)$ & 0.22 & $1.03(0.14,7.35)$ & 0.64 & 0 & 1.0 \\
\hline $\mathrm{TC}+\mathrm{CC}$ & $61(16.4)$ & $94(22.8)$ & 4.92 & $0.67(0.47,0.96)$ & 0.03 & $0.69(0.47,1.01)$ & 0.06 \\
\hline $\mathrm{T}$ & $679(91.5)$ & $730(88.4)$ & Reference & 1.00 & - & - & - \\
\hline $\mathrm{C}$ & $63(8.5)$ & $96(11.6)$ & 4.37 & $0.70(0.50,0.98)$ & 0.04 & $0.70(0.48,1.00)$ & 0.05 \\
\hline
\end{tabular}

${ }^{*}$ adjusted for age, gender, smoking, drinking, and family history of cancer.

TABLE 4: XRCC1 haplotype analysis of three polymorphisms in XRCC1 gene.

\begin{tabular}{|c|c|c|c|c|c|c|c|}
\hline Haplotypes & Case $N(\%)$ & Control N (\%) & $\chi^{2}$ & OR $(95 \% \mathrm{CI})$ & $P$ & OR $(95 \% \mathrm{CI})^{*}$ & $P^{*}$ \\
\hline CGT & $323(42.4)$ & $349(40.4)$ & Reference & 1.00 & - & - & - \\
\hline TGT & $152(19.9)$ & $189(21.9)$ & 1.11 & $0.87(0.67,1.13)$ & 0.29 & $0.81(0.60,1.10)$ & 0.18 \\
\hline CAT & $221(29.0)$ & $229(26.5)$ & 0.12 & $1.04(0.82,1.32)$ & 0.73 & $0.99(0.74,1.31)$ & 0.92 \\
\hline CGC & $57(7.5)$ & $89(10.3)$ & 3.93 & $0.69(0.48,1.00)$ & 0.05 & $0.62(0.40,0.96)$ & 0.03 \\
\hline CAC & $2(0.3)$ & $4(0.5)$ & 0.10 & $0.54(0.10,2.97)$ & 0.76 & $0.25(0.03,2.30)$ & 0.22 \\
\hline TAT & $3(0.4)$ & $1(0.1)$ & 0.33 & $3.24(0.34,31.32)$ & 0.57 & $3.60(0.36,35.79)$ & 0.27 \\
\hline TGC & $4(0.5)$ & $3(0.3)$ & 0.01 & $1.44(0.32,6.49)$ & 0.92 & $0.76(0.10,5.72)$ & 0.79 \\
\hline TAC & 0 & - & - & 一 & - & 一 & - \\
\hline Total & $762(100)$ & $864(100)$ & - & - & - & - & - \\
\hline
\end{tabular}

* adjusted for age, gender, smoking, drinking, and family history of cancer.

The order of three SNPs: codon 194, codon 399, and $-77 \mathrm{~T}>\mathrm{C}$.

researches showed to be consistent with ours. According to these results, Casson et al. [29] founded that there was no relationship between polymorphism of XRCC1 codon 194 and esophageal adenocarcinoma (EA) susceptibility in Canada population. Lee et al.s [30] study also found that there was no association between polymorphism of XRCC1 codon 194 and ESCC in Asia population. On the contrary, there are studies showing that XRCC1 codon 194 can increase the risk for EC. For example, the result of Xing et al. [31] indicated that the mutation homozygous genotype (TT) of XRCC1 codon 194 is the risk factor for EC, the adjusted OR (95\% CI) has a value of 1.98 (1.26-3.12). A case-control study of Liu et al. [32] in Hebei population of China found that the mutation homozygous genotype (TT) of XRCC1 codon 194 can increase individual risk of ESCC 0.86-fold (adjusted OR (95\% CI): 1.86 (1.192.88)).

Regarding the XRCC1 codon 399 polymorphism results, we have not seen any significant association with ESCC. According to this, Chen et al. [33] and Song et al. [34] conducted a case-control study in Jiangsu and Henan provinces of China, respectively, showing no association between XRCC1 codon 399 polymorphism and EC susceptibility. However, according to the results of Yu et al. [35], comparing with wild type (GG), the mutation homozygous genotype 
TABLE 5: Combination genotypes analysis of XRCC1 codons 194, 399, and -77T>C.

\begin{tabular}{|c|c|c|c|c|c|c|c|}
\hline Combined genotypes & Case $N(\%)$ & Control $N(\%)$ & $\chi^{2}$ & OR $(95 \% \mathrm{CI})$ & $P$ & OR $(95 \% \mathrm{CI})^{*}$ & $P^{*}$ \\
\hline CC/GG/TT & $39(11.2)$ & $43(10.6)$ & Reference & 1.00 & - & - & - \\
\hline $\mathrm{CT} / \mathrm{GA} / \mathrm{TT}$ & 68 (19.5) & $71(17.6)$ & 0.04 & $1.06(0.61,1.82)$ & 0.85 & $0.95(0.53,1.72)$ & 0.87 \\
\hline CT/GG/TT & 65 (18.7) & $72(17.8)$ & 0.00 & $0.99(0.58,1.72)$ & 0.99 & $0.88(0.49,1.60)$ & 0.68 \\
\hline CC/GA/TT & $60(17.2)$ & $66(16.3)$ & 0.00 & $1.00(0.57,1.75)$ & 0.99 & $1.02(0.56,1.87)$ & 0.95 \\
\hline TT/GG/TT & $29(8.3)$ & $37(9.2)$ & 0.19 & $0.86(0.45,1.66)$ & 0.66 & $0.91(0.45,1.84)$ & 0.80 \\
\hline CT/GG/CT & $16(4.6)$ & $38(9.4)$ & 4.35 & $0.46(0.22,0.96)$ & 0.04 & $0.52(0.24,1.13)$ & 0.10 \\
\hline $\mathrm{CC} / \mathrm{AA} / \mathrm{TT}$ & $23(6.6)$ & $23(5.7)$ & 0.07 & $1.10(0.53,2.27)$ & 0.79 & $0.86(0.39,1.92)$ & 0.72 \\
\hline $\mathrm{CC} / \mathrm{GA} / \mathrm{CT}$ & $17(4.9)$ & $23(5.7)$ & 0.28 & $0.81(0.38,1.75)$ & 0.60 & $0.74(0.32,1.70)$ & 0.48 \\
\hline CC/GG/CT & $20(5.7)$ & $22(5.4)$ & 0.00 & $1.00(0.48,2.11)$ & 1.00 & $1.09(0.50,2.42)$ & 0.82 \\
\hline $\mathrm{CT} / \mathrm{GA} / \mathrm{CT}$ & $4(1.1)$ & $2(0.5)$ & 0.23 & $2.21(0.38,12.71)$ & 0.63 & $1.18(0.18,7.74)$ & 0.86 \\
\hline CC/AA/CT & $1(0.3)$ & $3(0.7)$ & 0.14 & $0.37(0.04,3.68)$ & 0.71 & $0.37(0.04,3.87)$ & 0.41 \\
\hline CT/AA/TT & $3(0.9)$ & $1(0.2)$ & 0.31 & $3.31(0.33,33.13)$ & 0.58 & $3.74(0.36,38.83)$ & 0.27 \\
\hline Others & $3(0.9)$ & $3(0.9)$ & - & - & - & - & - \\
\hline Total & $348(100)$ & $404(100)$ & - & - & - & - & - \\
\hline
\end{tabular}

${ }^{*}$ adjusted for age, gender, smoking, drinking, and family history of cancer.

TABLE 6: Trend analysis of the number of mutation sites.

\begin{tabular}{|c|c|c|c|c|c|c|c|}
\hline Number of mutation sites & Case $N(\%)$ & Control N (\%) & $\chi^{2}$ & OR $(95 \% \mathrm{CI})$ & $P$ & OR $(95 \% \mathrm{CI})^{1}$ & $P^{1}$ \\
\hline 0 & 39 (11.2) & $43(10.6)$ & Reference & 1.00 & - & - & - \\
\hline 1 & $198(56.9)$ & $220(54.5)$ & 0.00 & $0.99(0.62,1.59)$ & 0.97 & $0.95(0.57,1.59)$ & 0.84 \\
\hline 2 & $107(30.7)$ & $139(34.4)$ & 0.41 & $0.85(0.51,1.40)$ & 0.52 & $0.78(0.46,1.36)$ & 0.40 \\
\hline 3 & $4(1.1)$ & $2(0.5)$ & 0.23 & $2.21(0.38,12.71)$ & 0.63 & $1.23(0.19,8.04)$ & 0.83 \\
\hline 二 & 一 & 一 & $0.38^{*}$ & 一 & $0.54^{*}$ & 一 & - \\
\hline Total & $348(100)$ & $404(100)$ & - & - & - & 一 & - \\
\hline
\end{tabular}

* trend chi-square.

${ }^{1}$ Adjusted for age, gender, smoking, drinking, and family history of cancer.

(AA) was a risk factor for developing EC (OR (95\% CI): 5.15 (2.42-10.93)). By stratification analysis, smokers carrying homozygous mutant (AA) were associated with a 7.31-fold increased risk for EC compared to smokers carrying the wild type (GG) (OR: 8.31, 95\% CI: 3.92-17.63), meanwhile drinkers carrying homozygous mutant (AA) were associated with a 4.43-fold increased risk for EC compared to drinkers carrying the wild type (GG) (OR: 5.43, 95\% CI: 2.46-11.99).

In this study we did not observe significant association between polymorphism of XRCC1 -77T $>C$ and EC susceptibility. Supporting these results, as Hao et al. [22] firstly reported the XRCC1 $-77 \mathrm{~T}>C$ polymorphism in $5^{\prime}$ noncoding region in 2004, the results found that XRCC1 $-77 \mathrm{~T}>\mathrm{C}$ can increase the combination of XRCC1 promoter and a transcription inhibitory factor, thus reducing the promoter activity and protein expression. However, they did not find the association of XRCC1 $-77 \mathrm{~T}>\mathrm{C}$ polymorphism with ESCC susceptibility. The relationship between $X R C C 1-77 \mathrm{~T}>\mathrm{C}$ and EC susceptibility needs to be clarified by more large size studies.

In this study, we conducted quality control strictly throughout the whole study. The patients included were all newly pathologically diagnosed, thus avoiding the prevalence-incidence bias. Besides, the controls were frequencymatched and the investigators were unified-trained rigorously. Moreover, we sequenced the three SNPs duplicately and verified them by DNA sequencing making the results credible.

In conclusion, the present study suggested that the single polymorphism in the DNA repair gene XRCC1 was not statistically associated with risk of ESCC; however, haplotype CGC (codon 194, codon 399 and $-77 \mathrm{~T}>\mathrm{C}$ ) of three SNPs in XRCC1 gene may decrease risk for ESCC susceptibility. But, in the future, it would be necessary to confirm these findings in a large and multiethnic population study because of the relatively small sample size in this study and geneenvironment interaction analysis and it should also be performed to investigate the tumorigenesis mechanism.

\section{Conflict of Interests}

The authors declare that there is no conflict of interests regarding the publication of this paper.

\section{Acknowledgments}

This research was supported by People's Republic of China (National Natural Science Foundation of China, no. 81072360) and Program for Science \& Technology Innovation Talents in Universities of Henan Province (no. 2010HASTIT027) and Excellent Youth Foundation of He'nan 
Scientific Committee (no. 124100510007). The authors acknowledge the blood samples of cases given by the First and the Second Affiliated Hospitals of Zhengzhou University. The authors also wish to acknowledge the residents in Xinxiang County of Henan Province who supported their epidemiological study on the scene.

\section{References}

[1] D. M. Parkin, F. I. Bray, and S. S. Devesa, "Cancer burden in the year 2000. The global picture," European Journal of Cancer, vol. 37, no. 8, pp. 4-66, 2001.

[2] J. Ferlay, H. R. Shin, F. Bray, D. Forman, C. Mathers, and D. M. Parkin, "Estimates of worldwide burden of cancer in 2008: GLOBOCAN 2008," International Journal of Cancer, vol. 127, no. 12, pp. 2893-2917, 2010.

[3] D. M. Parkin, F. Bray, J. Ferlay, and P. Pisani, "Global cancer statistics, 2002," CA: A Cancer Journal for Clinicians, vol. 55, no. 2, pp. 74-108, 2005.

[4] L. Dai, K. Wang, J. Zhang, Q. Lv, X. Wu, and Y. Wang, "XRCC1 gene polymorphisms and esophageal squamous cell carcinoma risk in Chinese population: a meta-analysis of case-control studies," International Journal of Cancer, vol. 125, no. 5, pp. 11021109, 2009.

[5] H. Yu, C. Fu, J. Wang, H. Xue, and B. Xu, "Interaction between $X R C C 1$ polymorphisms and intake of long-term stored rice in the risk of esophageal squamous cell carcinoma: a case-control study," Biomedical and Environmental Sciences, vol. 24, no. 3, pp. 268-274, 2011.

[6] A. Jemal, F. Bray, M. M. Center, J. Ferlay, E. Ward, and D. Forman, "Global cancer statistics," CA: A cancer Journal for Clinicians, vol. 61, no. 2, pp. 69-90, 2011.

[7] J. H. J. Hoeijmakers, "Genome maintenance mechanisms for preventing cancer," Nature, vol. 411, no. 6835, pp. 366-374, 2001.

[8] T. Lindahl and R. D. Wood, "Quality control by DNA repair," Science, vol. 286, no. 5446, pp. 1897-1905, 1999.

[9] R. D. Wood, M. Mitchell, J. Sgouros, and T. Lindahl, "Human DNA repair genes," Science, vol. 291, no. 5507, pp. 1284-1289, 2001.

[10] E. C. Friedberg, "DNA damage and repair," Nature, vol. 421, no. 6921, pp. 436-440, 2003.

[11] S. Maynard, S. H. Schurman, C. Harboe, N. C. de Souza-Pinto, and V. A. Bohr, "Base excision repair of oxidative DNA damage and association with cancer and aging," Carcinogenesis, vol. 30, no. 1, pp. 2-10, 2009.

[12] R. J. Hung, J. Hall, P. Brennan, and P. Boffetta, "Genetic polymorphisms in the base excision repair pathway and cancer risk: a huge review," American Journal of Epidemiology, vol. 162, no. 10, pp. 925-942, 2005.

[13] M. Stanczyk, T. Sliwinski, M. Cuchra et al., "The association of polymorphisms in DNA base excision repair genes XRCC1, OGG1 and MUTYH with the risk of childhood acute lymphoblastic leukemia," Molecular Biology Reports, vol. 38, no. 1, pp. 445-451, 2011.

[14] L. Cai, N. C. Y. You, H. Lu et al., "Dietary selenium intake, aldehyde dehydrogenase-2 and X-ray repair cross-complementing 1 genetic polymorphisms, and the risk of esophageal squamous cell carcinoma," Cancer, vol. 106, no. 11, pp. 2345-2354, 2006.

[15] G. Liu, W. Zhou, B. Y. Yeap et al., "XRCC1 and XPD polymorphisms and esophageal adenocarcinoma risk," Carcinogenesis, vol. 28 , no. 6, pp. 1254-1258, 2007.
[16] L. H. Thompson and M. G. West, "XRCC1 keeps DNA from getting stranded," Mutation Research/DNA Repair, vol. 459, no. 1, pp. 1-18, 2000.

[17] R. C. Sobti, J. Singh, P. Kaur, S. S. Pachouri, E. A. Siddiqui, and H. S. Bindra, "XRCC1 codon 399 and ERCC2 codon 751 polymorphism, smoking, and drinking and risk of esophageal squamous cell carcinoma in a North Indian population," Cancer Genetics and Cytogenetics, vol. 175, no. 2, pp. 91-97, 2007.

[18] H. Li, T. C. Ha, and B. C. Tai, "XRCC1 gene polymorphisms and breast cancer risk in different populations: a meta-analysis," Breast, vol. 18, no. 3, pp. 183-191, 2009.

[19] M. R. Shen, I. M. Jones, and H. Mohrenweiser, "Nonconservative amino acid substitution variants exist at polymorphic frequency in DNA repair genes in healthy humans," Cancer Research, vol. 58, no. 4, pp. 604-608, 1998.

[20] J. E. Lamerdin, M. A. Montgomery, S. A. Stilwagen et al., "Genomic sequence comparison of the human and mouse XRCC1 DNA repair gene regions," Genomics, vol. 25, no. 2, pp. 547-554, 1995.

[21] R. M. Lunn, R. G. Langlois, L. L. Hsieh, C. L. Thompson, and D. A. Bell, "XRCC1 polymorphisms: effects on aflatoxin B1-DNA adducts and glycophorin A variant frequency," Cancer Research, vol. 59, no. 11, pp. 2557-2561, 1999.

[22] B. Hao, H. Wang, K. Zhou et al., "Identification of genetic variants in base excision repair pathway and their associations with risk of esophageal squamous cell carcinoma," Cancer Research, vol. 64, no. 12, pp. 4378-4384, 2004.

[23] C. H. Lee, J. M. Lee, D. C. Wu et al., "Independent and combined effects of alcohol intake, tobacco smoking and betel quid chewing on the risk of esophageal cancer in Taiwan," International Journal of Cancer, vol. 113, no. 3, pp. 475-482, 2005.

[24] M. Siddiqi, R. Kumar, Z. Fazili, B. Spiegelhalder, and R. Preussmann, "Increased exposure to dietary amines and nitrate in a population at high risk of oesophageal and gastric cancer in Kashmir (India)," Carcinogenesis, vol. 13, no. 8, pp. 1331-1335, 1992.

[25] J. Li, L. Mu, and G. Wei, "Relationship between polymorphisms of DNA repair gene XRCC1 and susceptibility to lung cancer," China Oncology, vol. 15, pp. 335-338, 2005.

[26] E. J. Duell, R. C. Millikan, G. S. Pittman et al., "Polymorphisms in the DNA repair gene XRCC1 and breast cancer," Cancer Epidemiology, Biomarkers \& Prevention, vol. 10, no. 3, pp. 217222, 2001.

[27] S. G. Lee, B. Kim, J. Choi, C. Kim, I. Lee, and K. Song, "Genetic polymorphisms of XRCC1 and risk of gastric cancer," Cancer Letters, vol. 187, no. 1-2, pp. 53-60, 2002.

[28] S. Z. Abdel-Rahman, A. S. Soliman, M. L. Bondy et al., "Inheritance of the 194Trp and the 399Gln variant alleles of the DNA repair gene XRCC1 are associated with increased risk of early-onset colorectal carcinoma in Egypt," Cancer Letters, vol. 159, no. 1, pp. 79-86, 2000.

[29] A. G. Casson, Z. Zheng, S. C. Evans, P. J. Veugelers, G. A. Porter, and D. L. Guernsey, "Polymorphisms in DNA repair genes in the molecular pathogenesis of esophageal (Barrett) adenocarcinoma," Carcinogenesis, vol. 26, no. 9, pp. 1536-1541, 2005.

[30] J. M. Lee, Y. C. Lee, S. Y. Yang et al., "Genetic polymorphisms of $\mathrm{XRCC1}$ and risk of the esophageal cancer," International Journal of Cancer, vol. 95, no. 4, pp. 240-246, 2001.

[31] D. Xing, J. Qi, X. Miao, W. Lu, W. Tan, and D. Lin, "Polymorphisms of DNA repair genes XRCC1 and XPD and their 
associations with risk of esophageal squamous cell carcinoma in a Chinese population," International Journal of Cancer, vol. 100, no. 5, pp. 600-605, 2002.

[32] J. Liu, W. Lei, J. Ma, and R. Xue, "Correlation of DNA repair gene polymorphisms and esophageal canceTNM staging and regional lymph node metastasis," Chinese Journal of Thoracic and Cardiovascular Surgery, vol. 22, no. 5, pp. 315-317, 2006.

[33] M. Chen, J. Wang, G. Guo et al., "The single nucleotide polymorphism of DNA damage repair gene XPD Lys751Gln, XRCC1 Arg399Gln and genetic susceptibility for esophageal cancer," Journal of Fudan University (Medical sciences), vol. 35, no. 2, pp. 273-277, 2008.

[34] C. Song, W. Tan, and D. Lin, "Polymorphisms of DNA repair gene $\mathrm{XRCC1}$ in Chinese population and its relation to esophageal squamous cell carcinoma," Cancer, vol. 20, no. 1, pp. 28-31, 2001.

[35] H. P. Yu, X. Y. Zhang, X. L. Wang et al., "DNA repair gene XRCC1 polymorphisms, smoking, and esophageal cancer risk," Cancer Detection and Prevention, vol. 28, no. 3, pp. 194-199, 2004. 


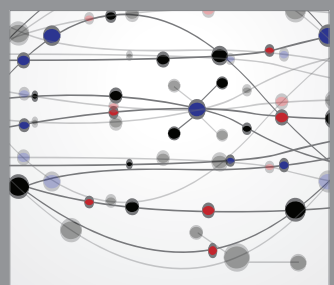

The Scientific World Journal
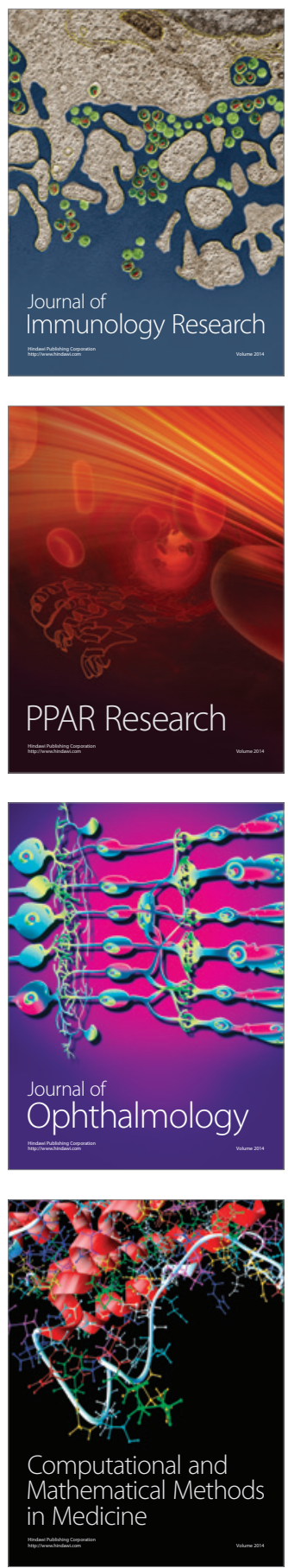

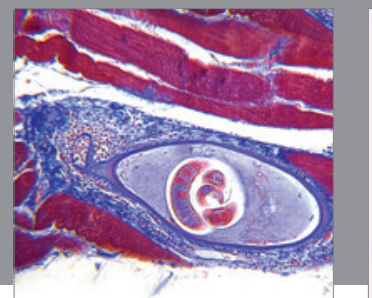

Gastroenterology

Research and Practice
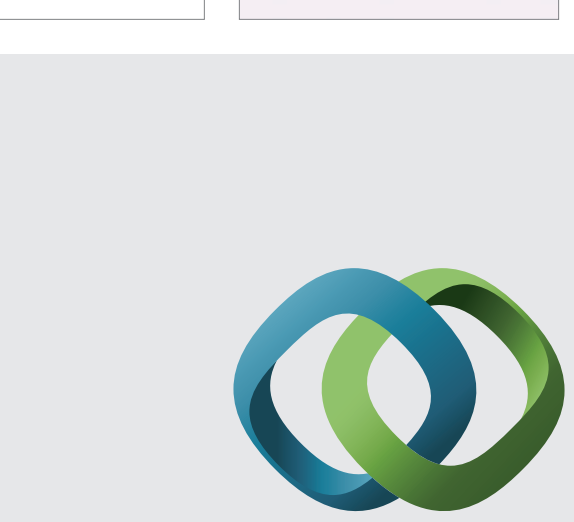

\section{Hindawi}

Submit your manuscripts at

http://www.hindawi.com
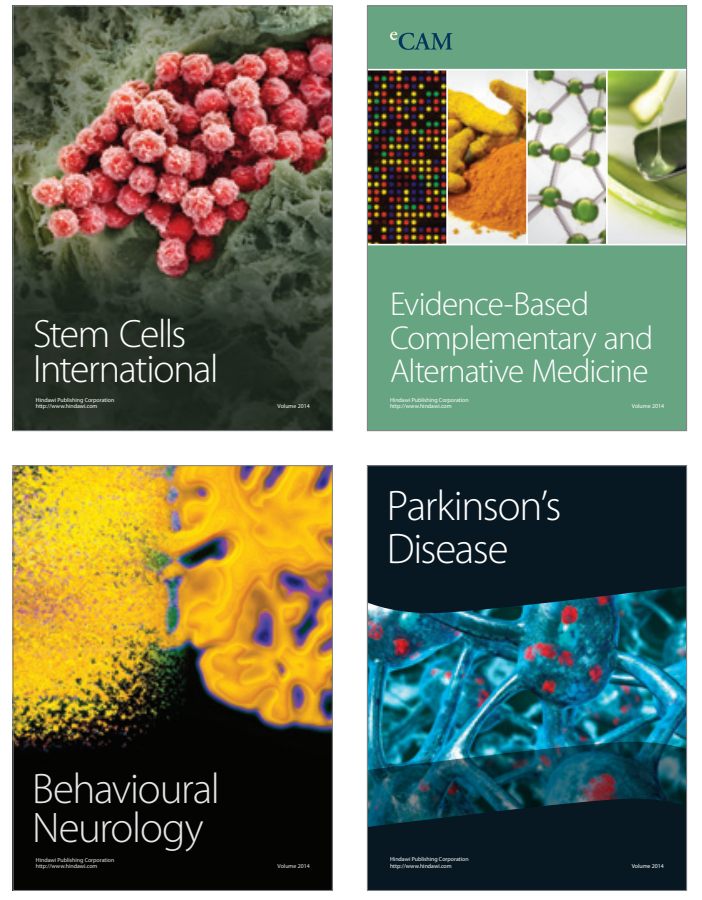
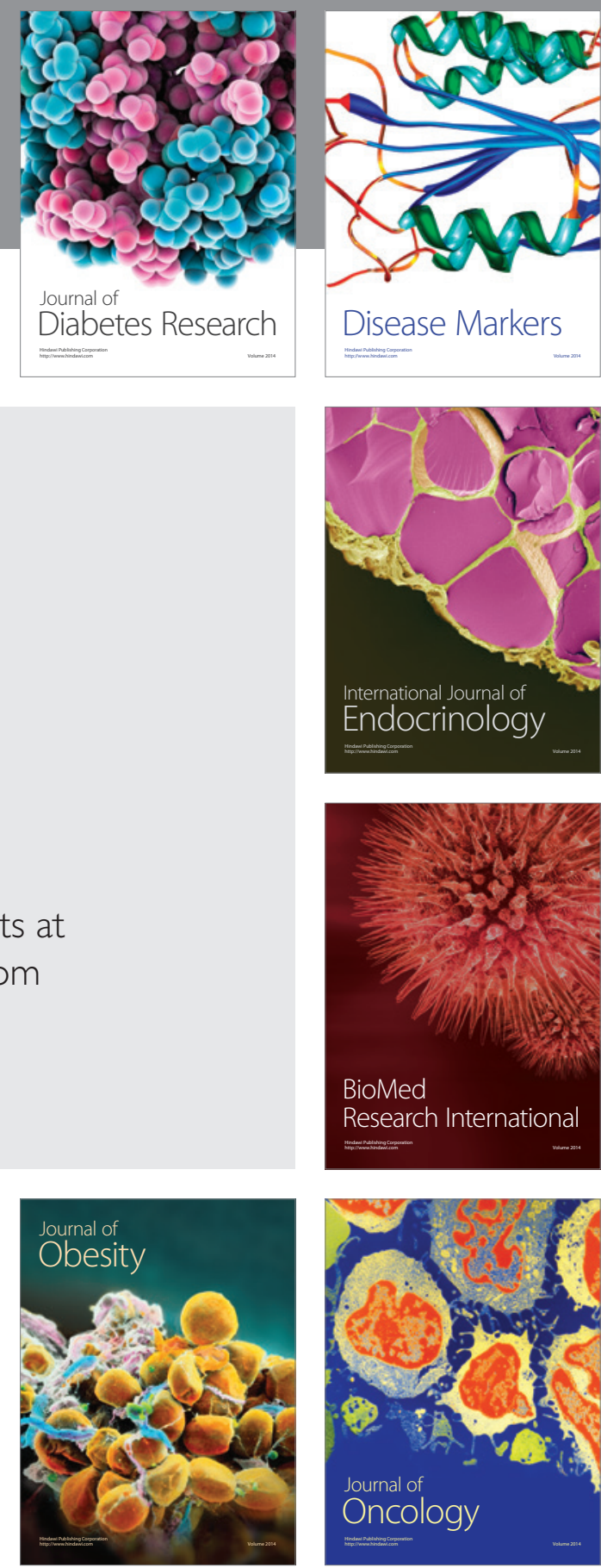

Disease Markers
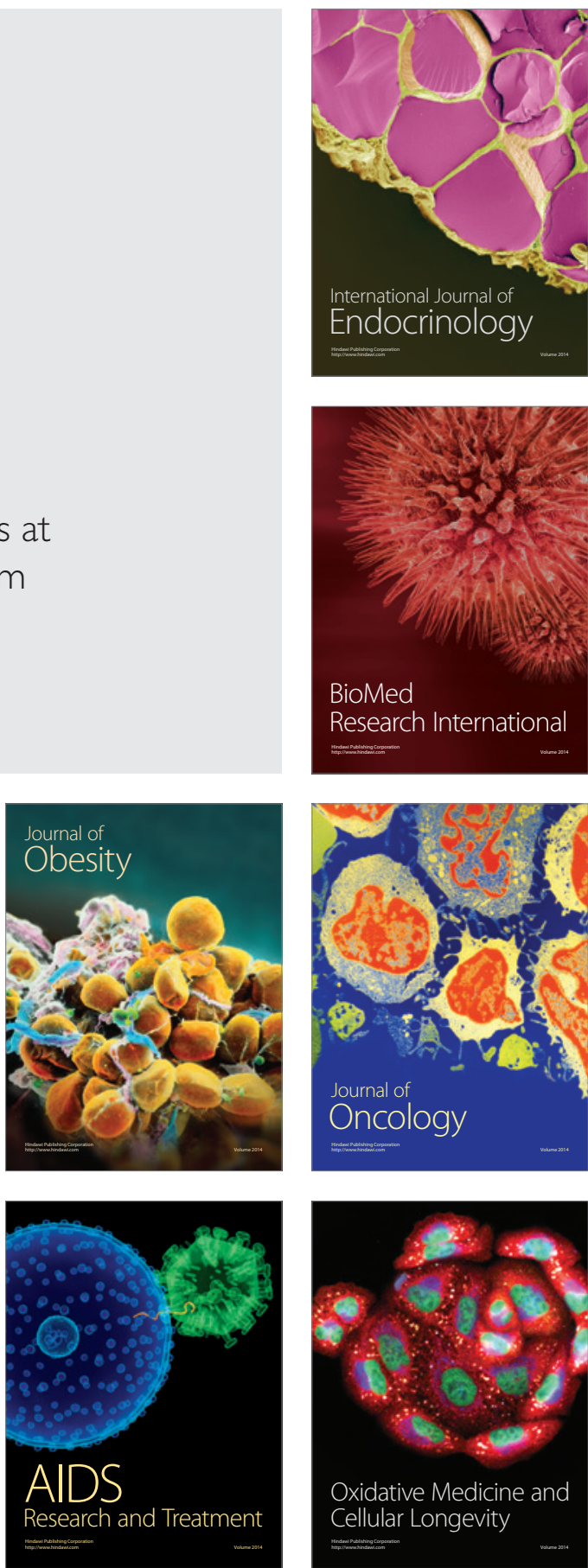